The Digital Object Identifier - DOI: 10.37952/ROI-jbc-01/19-59-9-58

Submitted on September 15, 2019.

\title{
Justification of the prospects of using phosphatotitanium ion exchangers for extracting rare earth metals from solutions of radionuclides
}

\author{
(C) Vladimir I. Ivanenko, ${ }^{+}$Roman I. Korneykov, and Nikita V. Zharov \\ Tananaev Institute of Chemistry-Subdivision of the Federal Research Centre "Kola Science Centre of the \\ Russian Academy of Sciences"; Science Centre of Russian Academy of Sciences. Academgorodok, 26 . \\ Apatity, 184209. Murmansk Region. Russia. Phone: +7 (81555) 79-204. \\ E-mail:ivanenko@chemy.kolasc.net.ru
}

\begin{abstract}
*Supervising author; ${ }^{+}$Corresponding author
\end{abstract}
Keywords: titanium phosphates, rare earth radionuclides, liquid radioactive waste, decontamination.

\section{Abstract}

The results of a study of the sorption properties of ion-exchange materials based on hydrated titanium (IV) oxohydroxophosphates with respect to rare-earth metal cations are presented in this paper. A high affinity of the latters for the sorption matrix in nitrate media was established, which is determined by the ion radius of the sorbate and increases in the series $\mathrm{Y}^{3+}<\mathrm{Gd}^{3+}<\mathrm{Eu}^{3+}<\mathrm{Sm}^{3+}<\mathrm{Nd}^{3+}<\mathrm{Ce}^{3+}$ at $\mathrm{pH}=4$ and $\mathrm{La}^{3+}<\mathrm{Ce}^{3+}<\mathrm{Y}^{3+}<$ $\mathrm{Yb}^{3+}$ at $\mathrm{pH}=1.5$ for all the studied sample compositions. It was experimentally shown that the doping of sorbents based on titanium(IV) oxyhydroxophosphates with zirconium(IV) cations, which differs from titanium(IV) in acid-base properties, leads to an increase in the sorption properties of ion exchangers, which allows the use of modified compositions for sorption of rare-earth metal cations from solutions with high acidity. It was established that partial dehydration of the sorption matrix and increase in temperature increase the sorption ability of ion-exchange materials. Sorption extraction of rare-earth element cations by sorbents of various compositions was carried out from solutions simulating real technological objects generated during the processing of nuclear fuel waste. It is shown that sorption materials based on hydrated titanium(IV) oxohydroxophosphates are promising ion exchangers for the extraction of rare-earth element cations from technological solutions with complex chemical composition. It was established that unmodified sorbent compositions are promising for the selective extraction of rare-earth element cations, while modified compositions are of interest for group sorption. The thermal treatment of a sorbent saturated with radioisotopes leads to the formation of crystalline insoluble mineral-like compounds, which ensures reliable immobilization of the sorbed components during long-term storage of the spent product.

\section{References}

[1] K. Elghniji, M.E.K. Saad, M. Araissi et al. Chemical modification of $\mathrm{TiO}_{2}$ by $\mathrm{H}_{2} \mathrm{PO}_{4}{ }^{-} / \mathrm{HPO}_{4}{ }^{2-}$ anions using the sol-gel route with controlled precipitation and hydrolysis: enhancing thermal stability. Materials Science-Poland. 2014. Vol.32. No.4. P.617-625.

[2] H.B. Ortiz-Oliveros, R.M. Flores-Espinosa, E. Ordonez-Regil et al. Synthesis of $\alpha$-Tii( $\left(\mathrm{HPO}_{4}\right)_{2} \cdot \mathrm{H}_{2} \mathrm{O}$ and sorption of Eu (III). Chemical Engineering Journal. 2014. Vol.236. P.398-405.

[3] Yu.M. Vishnyakov, S.P. Malyshev, V.M. Pchelintsev et al. Small-sized station for complex processing of liquid radioactive waste. Shipbuilding. 1999. No.3. P.44-48. (russian)

[4] B.E. Ryabchikov. Liquid radioactive waste treatment. Moscow: DeLi print. 2008. 516p. (russian)

[5] A.M. Abdel-Karima, A.A. Zaki, W. Elwana et al. Experimental and modeling investigations of cesium and strontium adsorption onto clay of radioactive waste disposal. Applied Clay Science. 2016. No.132133. P.391-401.

[6] M.S. Mansy, R.S. Hassana, Y.T. Selima et al. Evaluation of synthetic aluminum silicate modified by magnesia for the removal of ${ }^{137} \mathrm{Cs},{ }^{60} \mathrm{Co}$ and ${ }^{152+154} \mathrm{Eu}$ from low-level radioactive waste. Applied Radiation and Isotopes. 2017. No.130. P.198-205.

[7] A quick reference to chemistry. Kiev: Naukova Dumka. 1965. 835p.

[8] Md.R. Awual, T. Yaita, H. Shiwaku. Design a novel optical adsorbent for simultaneous ultra-trace cerium(III) detection, sorption and recovery. Chemical Engineering Journal. 2013. No.228. P.327-335. 
JUSTIFICATION OF THE PROSPECTS OF USING PHOSPHATOTITANIUM ION EXCHANGERS FOR...

[9] V.I. Ivanenko, R.I. Korneykov, E.P. Lokshin. Immobilization of metal cations by titanophosphate sorbents. Radiochemistry. 2016. Vol.58. No.2. P.140-146. (russian)

[10] V.I. Ivanenko, E.P. Lokshin, H.B. Avsaragov, N.A. Melnik, V.T. Kalinnikov. A method of producing a sorbent based on titanium phosphate. Patent RF, № 2246985. 2005. (russian)

[11] V.I. Ivanenko, E.P. Lokshin, R.I. Korneykov, V.T. Kalinnikov. A method of producing a sorbent based on titanium phosphate. Patent RF, № 2401160. 2009. (russian)

[12] V.I. Ivanenko, E.P. Lokshin, R.I. Korneykov et al. Increase in the performance of titanium phosphate sorbents by modifying with transition metal cations. Doklady Chemistry. 2011. Vol.439. No.4. P.493495. (russian)

[13] D.I. Ryabchikov, D.I. Ryabukhin. Analytical chemistry of elements. Rare earth elements and yttrium. Moscow: Nauka. 1966. 380p. (russian)

[14] E.A. Chuveleva, O.V. Kharitonov, L.A. Firsova. Sorption of REE and TPE on strongly acid sulfonic cation exchanger KU-2 from nitric acid media. Radiochemistry. 1994. Vol.36. No.5. P.410-413. (russian) 